\title{
TCF7 Gene
}

National Cancer Institute

\section{Source}

National Cancer Institute. TCF7 Gene. NCI Thesaurus. Code C97906.

This gene is involved in both transcriptional regulation and T-cell differentiation. 